\title{
Charting New Venues for Teaching Literary Texts through Black English Vernacular in EFL Context: Case of H.B. Stowe's Uncle Tom's Cabin
}

\author{
Yamina ILES \\ Language Studies \\ English Department, FLPATP lab N²7, \\ Abou Bakr Belkaid University,Tlemcen, Algeria \\ Correspondent Author: amina.iles09@ gmail.com \\ Amine BELMEKKI \\ Applied Linguistics \& TEFL \\ English Department, FLPATP lab Nº72, \\ Abou Bakr Belkaid University,Tlemcen, Algeria
}

Received : 12/29/2020 Accepted: 2/28/2021 Published :3/24/2021

Absract:

This research paper attempts at studying the operation of literary texts teaching through Black English Vernacular (BEV) in EFL context, selecting the American novel: Uncle Tom's Cabin, henceforth (UTC), (1852) by Harriet Beecher Stowe (1811-1896) as a parameter of research. Its main aim is to reveal and project the new venues for teaching literary texts through BEV in EFL classroom. The choice of this novel constitutes a luxuriant source of investigation. Additionally, it is abundant with various cultural elements used by its characters. The significance of the study relies on the examination and analysis of lexical items regarding the role of literature in the EFL context between the past and the present time. Also, with the difficulties of using literary texts as language tools in the EFL educational milieu. After implementing a stylistic analytical method on the selected novel, the results of the study end up by the selection of certain lexical entries from Black English that can be used as a reference in the teaching of literature in EFL contexts.

Keywords: Black English Vernacular, EFL context, H.B. Stowe, literary texts, Uncle Tom's Cabin

Cite as: ILES, Y., \& BELMEKKI, A . (2021). Charting New Venues for Teaching Literary Texts through Black English Vernacular in EFL Context: Case of H.B. Stowe's Uncle Tom's Cabin. Arab World English Journal, 12 (1) 128-138.

DOI: https://dx.doi.org/10.24093/awej/vol12no1.9 


\section{Introduction}

Various language teachers tend to disclose the potentiality of literary texts in terms of developing distinct features of a foreign language. Therefore, the importance of reading, mainly the task of culturally authentic texts, has become one of the central claims for syllabus restructuring in the EFL context. However, those syllabi are still in need of some teaching methods of literature especially with regard to American Literary dialect.

Many scholars, especially dialectologists, have been through time interested in studying dialect use since it is a very multifaceted linguistic performance spreading its roots not only to sociolinguistics but also to literature and EFL contexts. Like any other language, English has various non-standard forms, including Black English Vernacular. The latter, despite being informal, is the medium of many written American literary pieces where personal adventures and life experiences are the authors' authentic touch that invites the involvement of readers.

The use of dialect in American literature renders it a more effervescent and attractive field of work. More to the point, it helps to portray the reality of American society. Through this dialect, readers in the EFL context experience all the pleasure when reading a literary work written in a Black Vernacular. Accordingly, the scope of the current research paper highlights the credibility of teaching literature through Black English Vernacular in EFL setting via the implementation of the dialectal characteristics associated with their social parameters. Therefore, this work contributes to enlightening the relationship of literature with EFL English teaching and hence it aims at answering the following questions:

1. Can Black English Vernacular be used in teaching literature for EFL students?

2. What are the contributive items for the success of this teaching in relation to the standard language?

\section{Literature Review}

Teachers of literature have been using texts from novels and books as their authors wrote them, an activity that makes the teaching process a bit difficult to grasp. Thence, using literary texts in EFL classrooms was not successful when taken literally, since literature in itself is challenging as a subject of study. For this reason, an approach to literature teaching can be proposed within this work.

\section{The Use of Literature in EFL Context: between the Past and the Present}

In the early $20^{\text {th }}$ century, learning a foreign language through literature was a crucial element in the Grammar Translation Method. Literary texts in the target language are the use of the samples of good writing as Duff (1990) states, "illustrations of the grammatical rules" (p. 3). The focal point of this teaching method was on dominating language structures and jargon. Therefore, there was neither artistic interest nor interest in subjects.

Subsequently, the Grammar Translation Method fell in neglect in the mid-period of the $20^{\text {th }}$ century, a constant refusal to the employment of literature in the EFL context became the rule. Therefore, the language teaching method centered on translating classic 
literary texts was somewhat unproductive when teaching modern languages. Thus, the tendency was to eradicate literary texts from the EFL context to emphasize teaching language skills mainly. Furthermore, from the 40 s to the $60 \mathrm{~s}$, literature vanished from the language learning syllabus. Accordingly, linguistics became the focal point of the language programs (Widdowson, 1982).

Yet, the operation of teaching has witnessed a change by the first half of the 60s, and matters, began to change. The subject of teaching the target language through literature was first at the King's College conference on teaching held in Cambridge teaching in 1963. Hence, the significance of literary texts as a beneficial tool in the language teaching/learning process emphasized this seminar. Simultaneously, the traditional approach arrived for its inability to improve language skills and communicative abilities. Even though these trying, the use of literary texts in the EFL context has persisted disregarded for several years. Therefore, structural approaches to language teaching transferred literature to unconsciousness, like an unfashionable tool, while the functionalnotional method ignored literature as far as it required a communicative function (Llach, 2007). Hence, Topping (1968) reinforced the complete elimination of literature from the foreign language syllabus, addressing its structural complexity and its originality to the standard grammar rules. As the author cites, "literature did not seem to contribute to foreign language students in their achievement of linguistic proficiency" (p. 97).

Currently, further research is absorbed in this section to determine the positive outcomes of employing literature in distinct EFL contexts. Accordingly, much research describes again the role of culture and literature in language learning for "the development of language materials, syllabi, and curriculum, as well as to describe the affective nature of the interaction between the language learner and the literature of the target language" (Liddicoat, 2000, p. 40). Henceforth, an essential area of research deals with the welfares of literary texts as a crucial part of integrative language teaching (Bagherkazemi \& Alemi, 2010; Carroli, 2008; De Blasé, 2005). Furthermore, there are various scopes advantages of literature in evolving EFL skills, which are the discovery of Alderson (2000), Kern (2000), and Hur (2005), among others.

Despite all the efforts mentioned in the previous work towards the use of literature in the EFL context, there is still no agreement among language teachers and educators on literature integration into the EFL classroom.

\section{Difficulties of Using Literature in EFL Classroom}

Despite some advantages of using literature in the EFL classroom, there are also some chief difficulties that require further concentration, such as literary dialect itself. Literary dialects, dialect used in literature, involve the insertion of non-standard forms into the writing of short stories and novels as well. Some scholars have provided various definitions for the term. For example, in a similar line of thought, the importance of literary dialect as being helpful to concretely picture the identity of the characters performing in the novel or short story. Hence, the literary dialect is par excellence, the interpretation of a personage's speech conveyed specifically and meaningfully to the readership. 
Including literary dialect in American literature makes a revolutionary element in the field. Ferguson (1959) advocates that using dialectal forms in novels can be problematic in its written techniques but is so expressive that authors cannot avoid it, nor can they control its unemployment.

Even though, the fact that using daily speech forms in literature allows authors to show lay people's features of life, there are a lot of difficulties in linguistic choice. The author who inserts dialect in literature is the consideration of a writer who gives the real image of the story's characters and sweeps himself out of both processes of thinking and talking, which are the job of the personages only. The dialect is but a reflection of their educational background and attitudinal viewpoint.

\section{Teaching Literary Dialect in EFL contexts: Some General Ideas}

All the general notice towards the insertion of literary texts in the EFL classroom is undisputable. Some investigators and educationalists like Carroli (2008) and Deblase (2005) are lastly approaching to reflect literature as an effective instrument that can offer EFL learners with chances to progress distinct features of the English language skill and to excavate their awareness and attentiveness of the language ethnography.

Moreover, the greeting of the worth of the implementation of literary texts in the EFL contexts does not mean that educators have attained a compromise in terms of how to use literature in their classrooms, what genre of texts they should practice, or when is the best instant to commence employing literary texts. Consequently, there is still a discussion regarding these problems between language instructors and educators. Therefore, the goal and the significance of literature in the EFL contexts are still a matter of debate by certain linguists in the present time.

\section{H.B. Stowe's Biography}

The daughter of one of the most famous evangelical preachers of the pre-civil war era and an artist mother painting portraits on ivory, Stowe Harriet Beecher was born 14 June 1811 in Connecticut. Catharine Beecher became the most potent female influence in her sister Stowe's life, after she lost her mother at the age of five years old. With a short memory and her brilliant attitude, Stowe could brighten even within the remarkable Beecher family. When she had eight years old, Beecher arrived in the Litchfield Female Academy, a school founded to vindicate the equality of female intellect. She was one of her teachers, with an eagerness for writing since her young age. Harriet Beecher volunteered to write weekly essays at the age of nine. Then, she won the honor of having her composition read aloud at the annual school exhibit at the age of thirteen. Her father presents there, set up and asked who the writer was when he had the answer 'your daughter, sir', this for Stowe was, as she described later, the proudest moment of her life.

Indeed Harriet Beecher Stowe was the spearhead of many groups to claim and demand the rights of others. In a society and an era where women had little power, she could influence and attract many people only by her voice, words, and her writings. Beecher worked to solve various social issues as fighting slavery and giving women their rights, such as being an individual while married or voting, rights seen today as standard 
freedom. She was not, only a writer that fought in a time where literature was not as noted by D Hedrick (the writer of Harriet Beecher Stowe: a life), but she was also a philanthropist and an abolitionist.

\section{Summary of Uncle Tom's Cabin}

In Uncle Tom's Cabin's novel, Stowe's literary work is the primary chief novel written by a woman dealing with the beliefs of slavery. Therefore, Harriet Beecher Stowe puts her book in the antebellum period by the beginning of the Civil War and replied to the Fugitive Slave Act of state in 1850.

Moreover, the Mulatto relatives consist of George, Eliza, and Harry in Uncle Tom's Cabin's novel, Life among the Lonely. Therefore, Harriet Beecher Stowe seeks the heartlessness of slavery. For this account, Stowe's novel occurs to be the top-selling abolitionist novel of the nineteenth century. Henceforth, Stowe captures a critical view at all individuals implicated in the slave commerce like abused slaves, cruel slave catchers, white slave-holders, religious Christians, and corrupt politicians.

Besides, the remaining characters in Uncle Tom's Cabin like, Tom, George, and others, meet some of these individuals on their independence journeys. Therefore, we pursue the name Tom since he goes away down South, further into the rock bottom of slavery, to follow the mulattoes characters like George, Eliza, and their son Harry as they take a trip north to Canada. Stowe (1852) says that "Tom is an obedient and humble servant and Mr. Shelby's, his master's, “best hand” (p. 68).

Henceforth, Harriet Beecher Stowe portrays the distinctive experiences of black slaves as opposed to mulatto slaves. They are the consideration of the white individuals as slaves seeking their freedom. Therefore, she reveals the various elements that differ the mulatto from the black slaves as in describing their physical appearance in Uncle Tom's Cabin.

\section{Analysis of the findings}

\section{Examples of Literary Dialect Used in Uncle Tom's Cabin}

There is an immense number of forms of contractions employed in Uncle Tom's Cabin's novel. Therefore, the following table depicts some of these contractions used by different characters.

Table 1. A few forms of contractions employed in Uncle Tom's Cabin's novel

\begin{tabular}{lcc}
\hline Contractions' Form & Standard Form & Page number \\
\hline Ha'nt & Have not & 10 \\
Don't & Do not & 10 \\
'cause & Because & 10 \\
That's going & That is going & 11 \\
You'll let & You will let & 11 \\
I've got & I have got & 11 \\
There's been & There has been & 12 \\
\hline
\end{tabular}


Arab World English Journal (AWEJ) Volume 12. Number 1. March 2021

Charting New Venues for Teaching Literary Texts

ILES \& BELMEKKI

\begin{tabular}{lll}
\hline Mas'r & Master & 12 \\
'em & Them & 14 \\
Isn't & Is not & 14 \\
That's it & That is it & 14 \\
Can't & Can not & 16 \\
Aunty'd keep & Aunty would keep & 22 \\
'ccount & Account & 22 \\
O' & Of & 22 \\
Won't & Will not & 22 \\
Lor' & Lord & 22 \\
Cuttin' & Cutting & 22 \\
Cookin' & Cooking & 22 \\
Does n't know & Does not know & 23 \\
Bringin' & Bringing & 23 \\
Declar' & Declare & 24 \\
Mus'n't & Must not & 24 \\
T' other night & The other night \\
Al'ays & Always & 24 \\
'long & Along & 24 \\
Boun' & Bound & 24 \\
'pears & Appears & 24 \\
On 't & On it & 25 \\
'way off & Away off & 25 \\
\hline
\end{tabular}

Therefore, Harriet Beecher Stowe's book named Uncle Tom's Cabin refers to a portrayal related to a vernacular variety called Black English Vernacular. Moreover, it is very significant to state that the whole story Uncle Tom's Cabin is full of contractions used by slave characters since it denotes the Non-Standard form of language.

Plenty of contractions' forms finds in Uncle Tom's Cabin, and as, the case with Uncle Tom, a slave character as shown in the following table:

Table 2. Contracted words by Uncle Tom in the novel

\begin{tabular}{ll}
\hline Character & Contracted words \\
\hline Uncle & 'menber, o'yer, seein', Mas'r, an't going, natur, 'deem, thar's, 'em, nothin', nur, \\
Tom & $\begin{array}{l}\text { chil'en, ba'r, ye, ator, 'fraid, 'spectin', readin', jest, 'tan't, bein', on 't, o' me, } \\
\text { swarin', crackin', better 'n you, willin', crittur, agin. }\end{array}$
\end{tabular}

Hence, additional personalities in Beecher's book, similarly implement contractions in their dialogue as revealed in the following table: 
Arab World English Journal (AWEJ) Volume 12. Number 1. March 2021

Charting New Venues for Teaching Literary Texts

ILES \& BELMEKKI

Table 3. Contracted words by other personalities

\begin{tabular}{ll}
\hline Character & Contracted words \\
Ant Chloe & $\begin{array}{l}\text { Al'us, interestin', Mas'r, cuttin', 'ccount, an't much, o', meetin', 'em, } \\
\text { declar', boun'. }\end{array}$ \\
Sam & $\begin{array}{l}\text { 'magine, ridin', 'tall, gen'leman, getting', jist, 'varsal, o' day, minit, our 'n, } \\
\text { Mas'r, 'pinion, I car', yer's, 'Hio, 'markably, 'bout, bein' . }\end{array}$ \\
Andy & $\begin{array}{l}\text { Extro'rnary, fa'r, gen'ally, tryin', t' other, al'ays, mus'n't, 'll, ris, 'em, } \\
\text { ha'nt,'Lizy, 'em, 't . }\end{array}$ \\
Andy & \\
& $\begin{array}{l}\text { Nothin', ma'am, tellin', you's, it's jist, 't, 'fess, workin', I's used, n't, Mas'r, } \\
\text { know'd, you 's all, 'spects, o' har, 'bout, 'cause, han't, 'long, tan't, don't }\end{array}$ \\
Topsy &
\end{tabular}

Moreover, Uncle Tom's Cabin reveals the study of the data demonstrates that vowels and consonants have been sometimes deleted or added from words by characters as:

*Deleted vowels /a, e, o, i/ in:

'agin, 'bout, 'way, b'longs, car', 'Hio, 'pinion, 'ccount, off'n, natur, spos'n, 'magine.

*/i/ turns to /e/ in:

set, ef, tell.

*/e/ turns into /i/ in:

Git, yit, forgit.

*/o/ and /a/ turns to /e/ in:

yer, getherin'.

*Consonant

*Contracted /g/ from nouns and verbs in:

meetin', goin', cuttin', seein', interestin', mornin', crackin', swarin', willin', 'spectin', readin'. 
${ }^{*}$ Contracted /t/ in:

Mas'r, nex', inves', didn', breas', los', las'.

*Contracted /th/ from:

T' other, 'em,

/Consonant transformation:

/s/ and /d/ turns to /n/ in:

'yourn', 'hearn'

/s/ turns to / $\mathrm{x} /$ in: 'axe'

/k/ turns to /t/ in: 'ast'

Also, the novel obtains some other changes occur in pronouns, demonstrative pronouns, auxiliaries, verbs, and articles in terms of pronunciation used by Uncle Tom, as the following table discloses:

Table 4. Various dialectal utterances used by Uncle Tom in the Novel

\begin{tabular}{ll}
\hline Dialectal features & The standard form \\
\hline Dat & That \\
Dem & Them \\
We's & We are \\
De & The \\
Yer & You \\
Dunno & Don't know \\
Der & Their \\
Dese & These \\
Dey & They \\
Gwine & Going \\
\hline
\end{tabular}

Some of the words transform entirely by Uncle Tom, as shown in table five totally. 
Table 5. Other dialectal terms used by Uncle Tom in the novel

\begin{tabular}{lll}
\hline Character & Dialectal words & Words in the Standard \\
\hline Uncle Tom & Mas'r & Master \\
& Ator & After \\
& Nur & Nor \\
& Crittur & Creature \\
& Al'ays & Always \\
& Ye & You \\
& Cum & Come \\
& Wal & Well \\
\hline
\end{tabular}

Furthermore, some alteration joined to certain dialect characters' speech resembling Aunt Chloe and Topsy as presented in the next table:

Table 6. Dialectal words used by Aunt Chloe and Topsy in Stowe's Book

\begin{tabular}{ll}
\hline Dialectal words & The words in the Standard \\
\hline Gal & Girl \\
Nuther & Neither \\
Dun no & Don't know \\
Jist & Just \\
Spect & Expect \\
Ma'am & Madam \\
Minnit & Minute \\
La & Laws \\
\hline
\end{tabular}

Furthermore, the research work spots light on other dialectal utterances that unveil the double negation, which is the consideration of certain features related to Non-standard language; some of these utterances are to portray in the following table:

Table 7. Various utterances of double negation employed in Uncle Tom's Cabin's Novel

\begin{tabular}{lll}
\hline Double negation & Standard form & Page number \\
\hline I should n't need no clothes & I should not need any clothes & 172 \\
't would n't do, no ways & It would not do, any ways & 173 \\
Don't think nobody never made me & Do not think anybody ever made me & 159 \\
I never tells no lies & I never tells any lies & 161 \\
I an't a proposin' nothin' & I am not proposing anything & 170 \\
I wan't spectin' nothin' & I was not expecting anything & 173 \\
But it did n't do me no good! & But it did not do me any good & 190 \\
Dunno nothing 'bout love & Do not know anything about love & 191 \\
Never had nothing nor nobody & Ever had anything nor anybody & 192 \\
Could n't never be nothin' but a nigger & Could not ever be anything but a nigger & 192
\end{tabular}

Henceforth, the researcher can observe a vast range of dialectal utterances that contain the feature of double negation portrayed in Stowe's novel.

The following table will reveal some dialectal grammatical utterances used in the novel. 
Arab World English Journal (AWEJ) Volume 12. Number 1. March 2021

Table 8. Deviant grammatical forms by Aunt Chloe in Uncle Tom's Cabin's Novel

\begin{tabular}{ll}
\hline Character & Dialectal Grammatical Utterances \\
\hline Aunt Chloe & I likes, hev, I's, I's,I knows, gwyne, Dun no, I looks, I hearn. \\
& We doesn't, you telled, stories isn't, \\
& I grow'd, they was, I never tells. \\
& They's burnt, dunno, I spects, I an't used, I gets, does you know. \\
& You's all, you is, white folks is, niggers is, I loves candy and sich, "there \\
& an't nobody left now" \\
I's so awful, other folks hires out der niggers, I's a thinkin', de boys is big \\
enough. \\
He was gwine, I's nothin' but a nigger, "If they's to pull every spear o' har \\
out o' my head, it would n't do no good, neither"
\end{tabular}

\section{Discussion}

To conclude, one may say that this research paper is simply a research work that would probably bring a further step in a scientific adventure to a very particular and fascinating field of investigation, namely Literary texts in the EFL context. This research scope is just an attempt to uncover the significance of Teaching Literary Texts through Black English Vernacular in EFL Context especially by the implementation of the proposed lexical entries from the selected novel.

The achievement in acquiring a language determines of the students' attention and passion for the tools used in the EFL context. Hence, their willpower with the learning task, and the level of their focus and satisfaction. This type of learners' connection might come from the tools and lectures employed in the EFL classroom. This paper attempts to demonstrate that literature, when used appropriately, can be an operative instrument for developing target language skills. Accordingly, it leads us to more easily disprove the arguments of those scholars against the use of literature as an instrument for language teaching like Edmondson (1997).

It tries at the same time to shed light on language as it empowers literary works in the interpretation of literary texts, and how it facilitates the communication of ideas, express feelings, persuade, and present matters to different audiences. It is mainly because, in current times, language scholars began to vary their minds by recognizing that folks can display varieties of distinctive sorts of language just by reading a piece of writing.

Besides, in any speech community, language carries many means of interaction and reveals our social behaviour. For this account, it is a fundamental element in any literary work used side by side with different forms of Non-Standard language.

\section{Conclusion}

As a result, some crucial issues still require part of this research scope. One always wants additional experimental research to confirm particular different methods to the incorporation of American novels in the EFL contexts. Yet, it is vibrant, that a literary text as the American book helps a lot to contribute in the language classroom. Thus, it offers an inspiring determination for language learning and teaching due to its remarkable characteristics not willingly present in any other writing form. 
Consequently, the teaching of literary texts through Black English Vernacular, as the American novel Uncle Tom's Cabin by Harriet Beecher Stowe in the EFL contexts, may facilitate the task for language learners to acquire and memorize the Standard English. This latter, was initially written in a vernacular variety by various authors to portray an accurate picture of dialect personages. For this, it is highly recommended that researchers interested in literature can supplement this stylistic method by adding other lexical entries from other literary dialects which can be beneficial in the elaboration of syllabi designed for teaching English as a foreign language in general and teaching literature in particular.

\section{About the authors}

Yamina ILES is an assistant-professor at the Superior School of Management of Tlemcen, Algeria (ESMT). She is also a Ph.D. candidate in Language Studies and Sociolinguistic Variation at the University of Tlemcen. In addition, she is a member researcher in the FLPATP research laboratory under the supervision of Prof. Amine BELMEKKI. https://orcid.org/00000001-6400-5634

Prof. Amine BELMEKKI is a full professor at the University of Tlemcen, Algeria. He is also the head of a research laboratory Foreign Languages Policy in Algeria and Teacher Professionalism (FLPATP). He is also the head of two national research projects (PNR \& CNEPRU). His field of interest in mainly concerned with Applied Linguistics, TEFL, and Education Sciences as well. https://orcid.org/0000-0003-3818-2826

\section{References}

Amer, A. (2003). Teaching EFL/ESL Literature. The Reading Matrix, 3(2), 63-73.

Alderson, C. (2000). Assessing Reading. Cambridge: Cambridge University Press.

Bagherkazemi M., \& Alemi, M. (2010). Literature in the EFL/ESL classroom: Consensus and controversy. LiBRI. Linguistic and Literary Broad Research and Innovation, $1(1), 1-12$.

Carroli, P. (2008). Literature in Second Language Education. London and New York: Continuum.

DeBlase, G. (2005). Teaching Literature and Language through Guided Discovery and Informal Classroom Drama. English Journal, 95(1), 29-32.

Duff, A., \& Maley, A. (1990). Literature. Oxford: Oxford University Press.

Ferguson, C. (1959). Diglossia. Word, 15, 325-340.

Hur, H. (2005). Literature-based Activities and Language Socialization in an Elementary ESL Classroom. University Park: The Pennsylvania State University.

Kern, R. (2000). Literacy and Language Teaching. Oxford: Oxford University Press

Liddicoat, A. C. (Ed.). (2000). Teaching Languages, Teaching Cultures. Melbourne: Language Australia.

Llach, P. A. (2007). Teaching language through literature: the wasteland in the ESL classroom. Odisea, (8), 7-17.

Stowe, B. H. (1852). Uncle Tom's Cabin. New York: A.A. Knopf.

Topping, D. M. (1968). Linguistics or literature: an approach to language. TESOL Quarterly, 2 (2), 95-100.

Widdowson, H. (1982). The Use of Literature. In M. Hines, \& W. Rutherford (eds.), On TESOL 81.40 Washington, D.C.: TESOL 